\title{
Igreja católica, assistência social e caridade: aproximações e divergências
}

CLAUDIA NEVES DA SILVA*

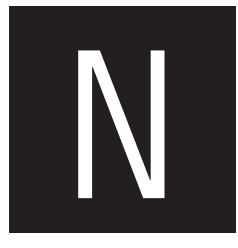

as duas últimas décadas, temos observado que as manifestações religiosas estão cada vez mais presentes nos diferentes segmentos da sociedade brasileira, motivando pesquisadores, em sua grande maioria da área de humanas, a desenvolverem pesquisas a respeito dessa temática.

M otivada por esta constatação, uma indagação surgiu: como as diferentes ações da Igreja Católica no âmbito social concebem o usuário da assistência social? A partir desta questão central, desenvolvemos uma pesquisa entre os anos de 1999 e 2003, a qual se propunha a investigar a concepção de direito social e caridade que as pastorais sociais da Igreja Católica apresentam em suas ações assistenciais, suas repercussões na política de assistência social no município de Londrina e a percepção daqueles que são alvo dessa ação.

Para concretização da mesma, entrevistamos os padres que assessoram as pastorais sociais - criança, menor, saúde, carcerária, sobriedade, terra, bem como a Sociedade de São Vicente de Paulo - e os respectivos coordenadores, tendo em vista que muitos dos católicos que desenvolvem atividades nessas pastorais, também estão presentes em diversos conselhos municipais. Realizamos também entrevistas com os atendidos, com a in-

* Doutoranda em História - UNESP/Assis. Professora do Departamento de Serviço Social da U niversidade Estadual de Londrina. Brasil. 
tenção de conhecer e analisar o que estes pensam sobre as ações da qual são objeto.

\section{O discurso da caridade}

Com o desenvolvimento de nosso estudo, verificamos que, impelidos pela concepção cristã de caridade, grupos de voluntários católicos praticam uma assistência baseada na idéia do amor fraterno às famílias carentes, mendigos, doentes, crianças abandonadas, deficientes físicos e mentais, assistência essa que não visa interesses pessoais ou recompensas materiais. Para exercê-la, segundo essa concepção, o critério exigido é a vontade de servir ao próximo, por ser um dever cristão para com os desfavorecidos, demonstrando, assim, um espírito nobre.

Essa concepção de caridade podemos encontrar em várias passagens da Bíblia, e a Igreja Católica, em virtude de sua hegemonia em nossa sociedade, difundiu-a por meio de um discurso repetitivo e moral, objetivando o equilíbrio e a harmonia entre os diferentes segmentos sociais, evitando assim, o perigo de conflitose revoltas daqueles que se encontram na miséria.

No trabalho desenvolvido pelas pastorais sociais, por entidades filantrópicas assistenciaise movimentos leigos, como a Sociedade de São Vicente de Paulo (SSVP), constatamos a presença de variados sujeitos sociais, tais como empresários, comerciantes e comerciários, profissionais liberais, donas-de-casa, funcionários públicos, empregadas domésticas, estudantes e professores, entre outros, os quais afirmam ter como princípio básico a caridade. De acordo com o “D ecreto sobre a atividade missionária da Igreja" (1966:19), publicação que resultou das discussões do Concílio Vaticano II, a caridade deve ser entendida como um ato de amor ao próximo: 
A caridade cristã a todos se estende sem distinção de raça, de condição social ou de religião. Ela não espera vantagem alguma nem gratidão. Foi com amor gratuito que Deus nos amou. Assim também os fiéis por sua caridade mostrem-se solícitos por todos os homens, amando-os naquele mesmo afeto que levou Deus a procurar o homem. À imitação de Cristo que percorria todas as cidades aldeias, curando toda doença e enfermidade em sinal da vinda do Reino de Deus (cf. 9, 35 ss; At 10, 38), a Igreja por seus filhos se liga aos homens de qualquer condição e particularmente aos pobres e aflitos, dedicando-se a eles prazerosamente (cf. 2Cor 12, 15).

O bservamos que a caridade é difundida como um dever cristão, como possibilidade de demonstrar perante a sociedade um caráter nobre e bondoso e não, como possibilidade de fortalecer os laços de solidariedade entre os membros de uma comunidade. Tendo por premissa básica o amor ao próximo, ela é considerada a base que levaria homens e mulheres a terem sentimentos e virtudes que seriam inerentes à natureza humana, como a bondade, a capacidade de perdoar, de acolher, a humildade, a aceitação mútua.

Neste sentido é que as religiões pregam a caridade enquanto virtude maior a ser alcançada (para este estudo, nos limitaremos às religiões cristãs), determinando que o encontro com Deus se dará de forma mais completa quanto mais o fiel praticar e viver a caridade, a fé e a esperança - a denominada virtude teologal, formulada por um dos disseminadores do Cristianismo, o apóstolo São Paulo (1Cor 13).

Segundo seus defensores, a caridade possibilita uma relação de união e comunhão com o outro, seu irmão, porque considerado filho do mesmo Pai, garantindo a salvação a rico e pobre, ou seja, a recompensa de uma vida eterna plena de amor e paz, já que os leva a ações de acolhimento e 
humildade: ao primeiro, porque ajuda e ao segundo, porque aceita o que Ihe é oferecido. $\mathrm{N}$ ão concebe $\mathrm{o}$ conflito e a discórdia entre quem tem mais e quem tem menos. Aliás, onde a caridade se faz presente, as desavenças desaparecem.

Diante desta perspectiva cristã, verificamos que a negação do conflito gera uma relação que se propõe de irmãos, mas não irmãos em condições de igualdade, porque um está em melhor situação social e econômica do que o outro: aquele que tem mais conquista a redenção através da doação, da esmola, visto que o Reino de Deus não é acessível para quem tem muitos bens materiais e não ajuda aquele que não tem condições de se manter; e o que tem menos permite que ambos conquistem a salvação, porque aceita sem reclamar o que lhe é dado, já que, por sua inaptidão, não conseguiu sobreviver sem a beneficência de outrem. Enfim, uma mútua aceitação.

Esta situação resultou em uma relação de submissão, na qual aquele que tem menos sujeita-se à vontade de quem tem mais, pois sua condição é conseqüência de problemas individuais que não foram superados, necessitando da intervenção de outro. A Igreja Católica, por sua longa experiência e tradição na prática de ajuda à população em situação de carência, qualquer que seja ela, desenvolve, através de seus membros, ações voltadas para 0 atendimento a essa população, seja a partir de ações individuais ou de instituições assistenciais.

Desta forma, em nome da caridade foram, e ainda são, construídas associações filantrópicas como asilos, albergues, creches, cujo fundamento são os valores quer da filantropia, quer da caridade cristã. Com este espírito, presta-se assistência material àqueles que nada possuem. M uitas dessas associações filantrópicas institucionalizaram-se formulando estatutos, adotando normas e critérios para o atendimento, em busca de recursos da comunidade e do Estado, tais como doações e isenções de impostos, para ampliação de seus serviços. 


\section{Um novo olhar sobre a realidade}

Desde a década de 60, a Igreja no Brasil vem passando por uma reorientação teológica e social em sua tradicional forma de agir. Por um lado, o Estado brasileiro passou a fundamentar sua legitimidade no discurso do desenvolvimento econômico que promoveria melhorias nas condições de vida dos trabalhadores, relegando para segundo plano a ideologia religiosa, que contribuía para garantir, através de um discurso anticomunista e de negação da existência de conflitos sociais, a manutenção da ordem política e econômica. Com o golpe militar de 1964, o discurso legitimador passou a fundamentar-se na doutrina de segurança nacional.

Por outro lado, com a emergência de lideranças leigas e populares no interior da Igreja, as repetidas falas de padres e bispos quanto à importância de uma harmonia e união entre patrão e empregado, ricose pobres, já não se justificava, visto que o aprofundamento do antagonismo de classes dificultava a difusão de uma ideologia de conciliação nacional (Camrgo, 1982).

Ainda de acordo com Camargo (1982), decresceu o interesse de colaboração entre Igreja e Estado, isto é, poder político e poder eclesiástico, e cresceu o contato com a massa de explorados e excluídos sociais: Nesta direção, elaborou-se na América Latina um novo pensamento teológico que procura se fundamentar na análise sociológica da realidade social e na releitura dos Evangelhos. (Camargo, 1982: 60). Práticas novas, como M ovimento de Educação de Base, Juventu de 0 perária Católica, Juventude U niversitária Católica, passaram a dividir espaços com práticas tradicionais, como Congregado M ariano, Filhas de M aria, Apostolado da O ração, havendo maior contato com a pobreza das cidades e campos. Tais práticas levaram a novos e diferentes discursos religiosos.

Diante desta nova situação que se apresentava, e em resposta aos desafios apresentados pelo Concílio Ecumênico Vaticano II, em 1965 foi aprovado o Plano de Pastoral de Conjunto da Igreja, como conseqüência de 
uma necessidade de renovar estruturas desta instituição religiosa. U ma ação evangelizadora mais ampla através do alargamento da participação dos membros da Igreja, ou seja, os leigos (Camargo, 1982). Além disso, uma nova teologia foi construída, tomando por base a realidade latino-americana, marcada pela concentração de riquezas e desigualdades sociais. Conforme Houtart (2003, p. 48), para a teologia da libertação:

O capitalismo significa a objetivação, a coisificação do conjunto do real em termoseconômicos, isto é, a transformação do cosmos em coisas, em objetos de troca rentáveis. A natureza se torna uma vasta mercadoria, o ser humano é reduzido a um simples homo economicus. A própria cultura é quantificada e entra na lógica do lucro.

Assim, partiu-se do pressuposto teológico de experimentar Deus no encontro com os excluídos sociais: criança, adolescente, homem, mulher, índio, idoso, pessoa portadora de deficiência. Pressuposto esse que se irradia da teologia da libertação e que, no dizer de Löwy (2000, p. 63) é produto espiritual do movimento social denominado cristianismo da libertação. Há vários princípios que regem a teologia da libertação. A matriz comum entre política e religião neste movimento é a fé.

Esta nova orientação aprofundou-se ainda mais, após a Segunda Conferência Geral do Episcopado Latino-Americano em Medellín (1968), Colômbia. Entre outras deliberações, houve uma revitalização da concepção de caridade, quando a crise econômica, política, social e ideológica tomava vulto na América Latina e o crescimento dos movimentos populares arregimentava um grande número de cristãos.

Esta situação gerou uma crise no interior da Igreja Católica LatinoAmericana, exigindo uma revisão de sua postura política ante o agravamento dos problemas sociais. Como conseqüência, surgiram e se fortaleceram as comunidades cristãs de base e as pastorais sociais, que difundiram e 
aprofundaram a expressão e a celebração da fé e da esperança ligadas a uma prática política.

As Comunidades Eclesiais de Base e as pastorais sociais se consolidaram por todo o Brasil ao longo da década de 70, graças aos incentivos de padres, leigos e religiosas das paróquias localizadas nos bairros da periferia. Sua principal característica consiste em discutir os problemas sociais, valendo-se da leitura do Evangelho e exigindo do poder público respostas às questões do cotidiano dos cidadãos. Q uanto às pastorais sociais, de acordo com a cartilha publicada pela Conferência Nacional dos Bispos do Brasil (CNBB, 2001, p.18), ela é:

Essa solicitude da Igreja voltada especialmente para a condição sócio-econômica da população. Hoje como ontem, ela se preocupa com as questões relacionadas à saúde, à habitação, ao trabalho, à educação, enfim, às condições reais da existência, à qualidade de vida...Ela expressa a compaixão de Jesus e o amor da mãe, traduzindo-os numa ação social de promoção humana junto aos setores mais pobres da sociedade.

Para verificarmos em que medida a nova orientação da Igreja repercutiu nas práticas de cunho caritativo, procuramos desvelar o significado das ações e relações que se estabelecem entre padres, coordenadores de pastorais e os atendidos.

No que se refere ao conceito de caridade, enquanto alguns padres apresentam-na como um ato de amor ao próximo, que conduz a atos de bondade e ajuda, outros a colocam como ponto de partida para ações que levam à mudança da situação observada no cotidiano da população:

E Jesus falava claramente isto: dar a vara e mandar pescar e não dar o peixe. Então o que Jesus queria dizer, vocês têm que partilhar, porque partilhando, as pessoas vão se sentir amadas. Resgatar a dignidade da 
pessoa. Ele não quer viver de esmolas. Ele quer ter também. ( 1)

A nossa percepção de caridade, o verdadeiro sentido da palavra, enquanto amor, está nisso: do serviço ao encarcerado. Nós vemos na pessoa do encarcerado o Jesus Cristo. Até mesmo no texto de Mateus diz: 'Toda vez que visitaste um preso, deste comida a um faminto, visitaste a um doente, foi a mim que o fizeste. (2 )

Acreditamos que estas ações diferenciadas acabam por levar a concepções diferenciadas. Os padres que estão mais próximos de pastorais que mobilizam, discutem e atuam nas questões relacionadas às políticas governamentais voltadas para o trabalhador ou para a área social, ap resentam um discurso de busca de respostas para a realidade social.

Assim, aquele que entra em contato com esta demanda se depara com uma situação, na qual a concentração de riqueza e a conseqüente falta de distribuição de renda geram a exclusão de grande parcela de mulheres, homens, idosos, jovens e crianças, dos bens e serviços da comunidade, revendo seus valores e conceitos de caridade e, muitas vezes, sua linha de ação pastoral, questionando o valor da caridade enquanto esta se apresenta como passiva e reforçadora de uma situação de submissão. Certamente há aqueles que não se deixam sensibilizar e reforçam uma atitude de suposta isenção diante da realidade social.

Q uando indagados a respeito do motivo de a Igreja voltar-se para os problemas sociais, houve unanimidade:

Porque é missão da igreja. Aonde foi Jesus na vida Dele? A missão de Jesus foi aos excluídos, aos pequenos da sociedade. $E$ ao fazer isto, Ele denunciava o status quo que se aproveitava desta pobreza toda para se sustentar no poder. ( 5 ) 
A igreja tem uma consciência muito lúcida no valor da pessoa humana. Então, aquela parte do Evangelho que diz que o próximo se identifica com o Cristo e que no dia do juízo final Ele vai perguntar: 'tive fome, tive sede, tive necessidades e você me atendeu, não me atendeu'. (4)

De acordo com Löwy (1998), a Igreja Católica colocou-se, desde o início da ascensão do modo de produção capitalista, contra a racionalização das relações comerciais, ou seja, contra as relações impessoais, movidas por interesses financeiros e econômicos, entre trabalhadores e patrões, não levando em consideração outros interesses ou valores, a não ser o lucro. Segundo a perspectiva da hierarquia católica, houve uma ruptura entre as exigências econômicas e o ideal cristão.

O capitalismo não poderia ser regulado por uma ética cristã e este era considerado por essa instituição religiosa, ateu, usurpador e um dos principais causadores das dificuldades dos mais pobres. Esta situação, alegavam, limitava o espaço para orientações e ações caritativas. A aversão ao capitalista e ao lucro proveniente desta relação, colocava em campos opostos Igreja Católica e capitalismo, desde o surgimento deste.

U ma outra razão da rejeição ao capitalismo por parte da Igreja seria a identificação de Jesus Cristo com o pobre, isto é, o Filho de Deus que veio ao mundo pobre, nascido em uma família pobre e que se colocou contra o poder econômico e político de sua época. Essa identificação levou membros da I greja a adotarem duas atitudes: a atenção caritativa para com o economicamente desfavorecido e a participação em movimentos baseados nas doutrinas que desafiam e combatem a injustiça social, denunciando o capitalismo como raiz do mal (Löwy, 1998).

Há que se destacar, no entanto, que esta posição anticapitalista da Igreja Católica teve, desde sua origem, uma tendência esmagadoramente conservadora, restauradora, regressiva (Löwy, 1998). U ma nostalgia por uma 
sociedade hierárquica pré-capitalista em que a Igreja detinha poderes excepcionais e suas opiniões e decisões eram encaradas como leis divinas, visto que ela era a representante do Apóstolo Pedro na terra. No entanto, essa aversão foi superada quando surgiu um inimigo maior: o movimento trabalhista socialista que, com suas lutas, alcançou significativas vitórias na Europa ante a intensa exploração do capital (Löwy, 1998).

Ainda segundo Löwy (1998), no final do século XIX, a Igreja viu-se obrigada a aceitar como irreversível, o advento do capitalismo e do Estado burguês. Com o agravamento da questão social e a desintegração dos laços sociais, ela buscou respostas para superar ou, ao menos, minorar tal situação. Ao mesmo tempo, deu-se o surgimento de uma esquerda católica, principalmente na França, o chamado "catolicismo social", que criticava o excesso de "capitalismo liberal", mas não desafiava a ordem social e econômica. Essa esquerda católica influenciou vários intelectuais da Igreja Latino-Americana, culminando com o surgimento e o fortalecimento da teologia da libertação.

Seguindo esta linha de raciocínio, as ações voluntárias de membros da Igreja Católica possibilitam que se estreitem os laços de solidariedade entre aqueles que estão próximos dos que vivem em extrema pobreza. No entanto, notamos que essa solidariedade fica, muitas vezes, limitada às ações no plano individual.

\section{Caridade e solidariedade: uma nova concepção?}

As entrevistas com os coordenadores das pastorais sociais não diferiram substancialmente das opiniões observadas junto aos padres, assessores dessas pastorais. Também para os primeiros, suas atividades são movidas pela idéia de caridade, que se fundamenta no amor fraterno ao próximo e se expressa na experiência da solidariedade em relação ao outro que se 
encontra em situação que Ihe impossibilita garantir sua condição mínima de sobrevivência, conduzindo esses coordenadores a diversas formas de ação que julgam necessárias para a defesa e garantia dos direitos individuais e coletivos:

A caridade é exatamente o amor que se compromete com a vida, não é você prestar um serviço meramente assistencial, protecionista, onde você olha a pessoa de cima, um pobrezinho, você vai fazer uma caridade, é um termo até pejorativo chamar isso de caridade, então a verdadeira caridade promove, ela é o amor, ela se doa. (C)

Ao meu ver caridade é você participar da vida da pessoa, não ali naquele momento crucial, extremo, mas ter uma vida relacionada a essas questões, então se você vê que a pessoa não tem casa, é você estar lutando para que aquela pessoa tenha uma casa, é você também estar junto para que todas as pessoas tenham direito à casa...(R)

Constatamos que, ao menos no discurso, as ações desenvolvidas não se limitam a fornecer cesta básica, roupas ou remédios. Há uma preocupação de que esta caridade possibilite a superação da situação de miséria em que vivem aqueles que são atendidos pelas pastorais. Preocupação essa que também está presente em documentos da CNBB. De acordo com a Cartilha "O que é pastoral social?", a Igreja demonstra a compaixão e amor de Jesus pelo ser humano através de ações de promoção humana junto aos setores marginalizados da sociedade:

Os Atos dos Apóstolos, as Cartas e o Apocalipse revelam igualmente a atenção das primeiras comunidades para com os pobres. Desde cedo, os cristãos se organizam para suprir as necessidades básicas de seus irmãos. Como mostra São Pedro em sua primeira carta, as comunidades eram 'uma casa para quem não tinha lar'. (CNBB, p.18) 
A ação destes agentes é movida pela convicção de que suas intervenções levarão a mudanças na condição de vida daqueles que são atendidos ou mesmo a mudanças sociais e econômicas, o que explica o fato de que, para alguns, a ação caritativa deve levar a uma ação política:

Nós temos um trabalho junto com outras igrejas e o objetivo dela é estar ao lado do homem do campo, tanto junto com a questão fé, da esperança do homem do campo, nos momentos de sofrimento, na animação, ajudando a animar as pessoas que vivem no campo...(T)

A conseqüência do maior contato de membros da Igreja com a realidade social teve como desdobramentos, a reconsideração de que a caridade não deve ser mais percebida apenas em seu aspecto afetivo, de assistência e diálogo entre as classes e grupos sociais. Ao contrário, de acordo com LIBÂN IO (1982: 139), a caridade, diante de uma situação de pobreza extrema, falta de recursos, passa a ser percebida enquanto

U ma caridade práxica que implica numa análise objetiva da realidade e num colocar-se do lado de um dos pólos conflitivos. A caridade é conversão e esta passa, freqüentemente, pela experiência dura e dolorosa do conflito. Somente assumindo o conflito na sua rudeza, o homem é capaz realmente de amar com objetividade. 0 conflito pode ser uma mediação da caridade, pois somente através dele consegue-se criar condições objetivas de justiça e de amor para uma classe, para muitos seres humanos.

É importante destacarmos, todavia, que ainda há muitos grupos de leigos que exercem uma caridade afetiva, assistencial e de colaboração, cuja característica principal podemos definir como a de minimizar o aspecto "feio e desagradável" da desigualdade social, promovendo a solidariedade entre aqueles que têm mais e aqueles que têm menos, mas não entre iguais. 
Mas, nas entrevistas com coordenadores de pastorais sociais, pudemosnotar que muitos adotaram uma nova prática social, destacando a necessidade de mudanças na direção política e econômica para combater a pobreza. Hoje, este discurso é repetido por muitos católicos:

Na nossa Igreja nós seguimos a palavra de Jesus nosso mestre, então nós temos que lutar por isso também. Pela igualdade social para todas as questões que envolvem os problemas sociais, a fome, a falta de moradia, o problema da terra. Aspessoas interpretam mal e dizem que a Igreja não devia se envolver com isso, que a Igreja não deve se envolver em política, mas deve sim, porque a igreja tem que ter seus representantes lá dentro da política também...(A)

A concretização da teologia da libertação deve ocorrer através de ações sociais e específicas que promovam e fortaleçam gestos de solidariedade para com os excluídos e entre estes. As pastorais sociais, entendidas como um agir de leigos da Igreja na sociedade, tornam-se o espaço no qual se darão as ações de solidariedade. De acordo com a CNBB, essas pastorais têm por objetivo:

Desenvolver atividades concretas que viabilizem essa transformação em situações específicas, tais como o mundo do trabalho, a realidade das ruas, o campo da mobilidade humana, os presídios, as situações de marginalização da mulher, dostrabalhadores rurais, dos pescadores, e assim por diante. (CNBB, 2001: p. 22)

Nas entrevistas realizadas, verificamos que esta orientação da CNBB é seguida pelos seus membros nas ações desenvolvidas junto aos atendidos pelas pastorais, as quais devem ser constituídas, entre outros aspectos, pela solidariedade, porque, segundo a Igreja, nas ações de Jesus Cristo para com os pobres, a solidariedade foi o elemento central. $D$ iante desta constatação BINGEM ER (1994: 301) afirma que: 
Crescer em solidariedade, viver a solidariedade é, portanto, segundo a fé cristã e o ensinamento da Igreja, viver uma ética que leva continuamente ao reconhecimento da dignidade pessoal do outro - seja qual for seu estado de vida e condição social- em pé de igualdade consigo mesmo e ao compromisso com a vida de todos, particularmente dos pobres e dos inimigos.

Para esta investigação, definimos solidariedade como sentimento de responsabilidade e dever para com o outro, sentimento que envolve reciprocidade, responsabilidade e dever de um grupo com outro grupo, ou de um indivíduo para com outro indivíduo.

O sentimento de solidariedade é tão mais importante à medida que leva aquele que exerce ações solidárias ao reconhecimento do problema do outro que se encontra em posição econômica e social desfavoráveis, incentivando à busca de sua superação, seja através de ações emergenciais e fragmentadas como a doação de alguns itens da cesta básica por ocasião de catástrofes naturais, seja através de engajamento em movimentos sociais, associações e cooperativas.

É importante ressaltarmos que a idéia de solidariedade, nos últimos 15 anos, tem levado a ações solidárias fundamentadas em valores como reciprocidade, união e colaboração entre grupos sociais distintos, como patrão e empregado, ricos e pobres.

Neste sentido, as ações solidárias que poderiam permitir a organização dos trabalhadores em busca de melhores condições de trabalho e de vida - saúde, habitação, educação, lazer - acabam por estimular uma "convivência solidária" entre grupos e classes sociais, porque unidas por um mesmo ideal: uma sociedade solidária, destituída de conflitos, já que aqueles que se encontram em melhor posição social e econômica, contribuirão para diminuir os problemas sociais que eclodem diariamente nas cidades ou nos bairros: a fome, o aumento do consumo de drogas, a violência, cujas causas estariam na pobreza local ou na falta de atitude dos governos. 
Portanto, se as ações voluntárias propiciam inovações, flexibilidade e variedade nos trabalhos junto à população carente de bens e serviços, por outro lado, constata-se o caráter instável e incompleto dessas ações porque, na maioria das vezes, não garantem direitos sociais e são algumas vezes excludentes e opressoras, visto que estabelecem critérios para sua concretização, tal como o indivíduo ter um comportamento de acordo com as normas estabelecidas pelos voluntários e não reclamar do serviço.

Seja como for, a CNBB (2001: p. 19) destaca que a solidariedade, conforme a perspectiva católica, deverá ser concretizada:

Na mão estendida às situações de emergência, de carência, de extrema pobreza, de fome. Não basta ser sensíveis. É preciso descruzar os braços, arregaçar as mangas e passar à ação. Um gesto, um mutirão, uma campanha - constituem expressões vivas da solidariedade. A solidariedade se expressa também, no apoio às lutas e movimentos sociais por melhores condições de vida e trabalho.

De acordo com os coordenadores, as pastorais não deixam de atender a esta solicitação quando da realização de suas atividades:

Esse trabalho nosso, no ano internacional do voluntariado, o nosso trabalho é voluntário, gratuito, porque você faz de coração... porque se você não tiver esse espírito de solidariedade você desanima na primeira visita, tem que ser muito perseverante, é uma palavra marcante no nosso trabalho, a perseverança. (S)

Reforçando o que já foi dito, este laço de solidariedade que deveria fortalecer a união entre pessoas e grupos sociais, passou a ter uma nova utilização com a reorientação política e econômica que o Estado brasileiro vem sofrendo ao longo das décadas de 80 e 90.

A partir do fortalecimento da perspectiva neoliberal de que o mercado é o espaço legítimo para resolução dos problemas econômicos e sociais, 
assim como para regulação das relações sociais, subord inando os interesses e necessidades sociais às estratégias mercantis, o Estado, para implementar essa política neoliberal, entre outras medidas, apropria-se da idéia de cooperação solidária entre indivíduos e grupos sociais e passa a utilizá-la como instrumento para livrar-se da pressão da sociedade civil por ações mais efetivas ante as desigualdades sociais.

No que diz respeito à área da assistência social, caberia à sociedade civil a construção e manutenção de instituições de atendimento às famílias em situação de risco social: criança, idoso, pessoa portadora de deficiência, estabelecendo parcerias com os governos municipais e estaduais. Assim, ela permite ao Estado diminuir seu espaço de atuação na área social, através da redução do orçamento destinado às políticas sociais e da redução de funcionários para este setor, repassando para a sociedade civil, a responsabilidade no atendimento à população excluída de bens e serviços.

0 resultado desta omissão, é a promoção da "privatização da assistência" (NETTO, 1999), como tantas outras privatizações de empresas e serviços estatais ocorridas no período. Conforme nos diz GU SM ÃO (2000: 107):

Segundo a proposta do governo, é necessário que a sociedade se torne parceira do Estado, partilhando com ele o enfrentamento das desigualdades sociais. Essa parceria deve envolver a solidariedade de organizações não-governamentais e populares, sindicatos, universidades, igrejas e empresas. O Estado perde a primazia na responsabilidade da questão social.

No que se refere às ações das pastorais sociais, também não foi diferente, estabelecendo-se parcerias entre governo e algumas pastorais:

O que a gente procura é estar sempre participando das discussões que a prefeitura realiza no campo social, 
no caso a Secretaria de Assistência Social nós temos representantes em alguns conselhos, no conselho da merenda, no PRO VOPAR...estamos atuando junto com o município na criação do conselho municipal dosusuários de drogas. $(R)$

O utrossim, as atividades das pastorais sociais têm mobilizado dezenas de voluntários, que atendem outras dezenas de pessoas. U ma ação que é de pouca visibilidade, agindo em locais em que o poder público tem pouca ou nenhuma ação, substituindo-o na maioria das vezes.

senhoras de 90 anos de idade. (C) Nós temos 9.384 famílias atendidas na Arquidiocese de Londrina, 1.082 líderes, crianças atendidas são 15.003 e 371 gestantes. Entre essas líderes, a maioria é de senhoras, donas-de-casa, muitas trabalham e aproveitam os finais de semana para esse trabalho, mas têm outras já aposentadas, temos também jovens líderes e até

Nos projetos nós temos uma média de 300 pessoas diretamente, isso com os projetos financiados e agora se formos calcular os projetos desenvolvidos em parcerias vai dar muito mais, então é uma população altamente carente. $(R)$

0 trabalho das pastorais abrange diferentes e diversos bairros de Londrina, o que, por certo, ocorre em outros municípios. U m trabalho de cooperação solidária entre os cidadãosque o poder público não pode descartar, ao contrário, utiliza-se largamente dele.

Se por um lado, as atividades das pastorais reforçam a omissão do Estado no enfrentamento da questão social, assumindo e cumprindo tarefas que extrapolam seus objetivos, exigindo maior número de voluntários, não atendendo todos que necessitam, por outro lado, elas levam muitos desses voluntários a um engajamento político, ampliando seu campo de ação através da articulação com movimentos ou organizações sociais e da participa- 
ção em diferentes conselhos - educação, saúde, assistência social, antidroga - reforçando a noção de que assistência social deve ser garantida como um direito social:

M esmo vivendo em um período em que o Estado se omite em sua responsabilidade no trato da questão social, a tentativa de refilantropização da assistência social (YAZBECK, 1996) por parte do Estado, a valorização do trabalho voluntário em detrimento da qualificação profissional para atuação na área social, aqueles que atuam nas pastorais sociais movidos por valores como amor ao próximo, solidariedade, não perderam de vista, ao contrário, reforçam a idéia de direito social:

(...) porque a caridade muitas vezes não é você dar prato de comida, mas pegar uma pessoa e mostrar que ela tem direitos, mas que ela tem que lutar por isso e tenho certeza que ela pode, tem condições para isso. (T)

A despeito de os coordenadores de pastorais apresentarem um discurso de renovação das estruturas sociais, constatamos que há uma distância substancial nas ações do dia-a-dia junto aos atendidos por essas pastorais. Se, na esfera do discurso, palavras como direito, mudança social e política, solidariedade são comuns, o que verificamos, ao entrevistarmos esses atendidos, é que as ações desenvolvidas estão longe de promoverem estes objetivos, como veremos a seguir.

\section{A percepção do público-alvo das pastorais sociais}

Nas entrevistas realizadas com pessoas atendidas pelas pastorais, estas afirmam que, quando precisaram de ajuda para pagar suas contas ou para comprar alimentos ou remédios, já haviam percorrido outros lugares, como a prefeitura e entidades assistenciais, demonstrando que conhecem 
o caminho para chegar aos "locais de ajuda", isto é, o tradicional caminho de ajuda informal, e até mesmo o discurso que deve ser reproduzido para obtê-la:

Já fui na Sagrada Coração de Maria, na LBV, no Sinal Verde (lá na rua Belém), na Provopar. No Sinal Verde (Projeto social da Prefeitura), eles falaram que iam fazer uma visita mas não vieram. Já fui na catedral também. (Maria)

Já pedi (na prefeitura), fui uma vez só, pedi para pagar luz, água, já faz tempo já. Só que agora eles cortaram isso, eles não dão mais prá ninguém. Foi antes de eu estar pedindo para os Vicentinos. (Lia)

A casa é um barraco de poucos cômodos e não consegue abrigar tod os os membros; 0 alimento não é suficiente para matar a fome; o remédio não pode ser comprado porque não há o dinheiro necessário; a violência doméstica, a briga entre vizinhos, a "guerra" entre gangues de jovens ou entre quadrilhas de traficantes e suas conseqüências reverberando naqueles que moram ao redor, levando a violência diária a apresentar sua face de terror. Situações que são enfrentadas cotidianamente, fazendo a realidade resumir-se a este embate diário:

Eles vieram aqui, viram as condições que eu tava. Porque no começo, eu fiquei na dificuldade, porque meu marido foi preso, eu não sabia mexer com nada, não entendia como mexia com o papel. Só que de lá dentro, ele foi me explicando e eu fui fazendo do jeito que ele tava me explicando. (Ana)

Eu fui procurar os vicentinos porque eu estava passando bastante necessidade, eu estava desempregada e estou desempregada ainda, né, então só ele trabalhando nós precisava de ajuda, aí eu fui atrás dos vicentinos. Faz 4 meses. (Carmem) 
A luta pela sobrevivência exige de homens, mulheres, idosos e adolescentes estratégias diárias para superar a falta de recursos para comprar os produtos minimamente essenciais, impedindo, na maioria das vezes, qualquer outro tipo de ação a longo prazo, já que a emergência do imediato exige deles ações que excluem a possibilidade de mobilização e organização para conquista e garantia de direitos. Nas relações que estabelecem com os vizinhos e amigos, constatam que vivenciam as mesmas situações, trocando informações e experiências, em busca de soluções emergenciais. Entre estas procuras, encontra-se a ida às pastorais sociais:

Uma senhora vendo a situação da gente falou por que vocês não procuram os vicentinos, eu falei: é verdade! A sociedade vicentina tem aqui também, e ela disse: tem né... aí foi onde nós procuremosné, amor! Aí nós procuremos eles e imediatamente se dispuseram ao apoio que eles puderam fazer e estão fazendo até hoje eles estão acompanhando a gente, estão orientando a gente nas questões tanto social quanto do estômago...(Carmem)

Constatamos que os princípios altruístas dos católicos orientam os trabalhos solidários junto a estas famílias, e esses trabalhos podem perdurar por vários meses, chegando a completar anos, tendo em vista a precária situação socioeconômica destas famílias, agravada muitas vezes pela doença e idade avançada. M as estas ações solidárias podem ocasionar o estabelecimento de uma relação, ao mesmo tempo, de solidariedade, dependência e submissão:

Eles viram que eu precisava, é que eu tinha problema, né. Eu fui transplantada do rim. Daí eu não podia fazer nada não podia trabalhar, fazer nada. (Ester) 
O fato demonstra que a cooperação solidária dos membros das pastorais, se é necessária e urgente para enfrentar uma situação emergencial, por outro lado não avança em busca de soluções para superar a situação de miserabilidade destas famílias, já que as ações limitam-se aos problemas imediatos. Como já foi dito anteriormente, a solidariedade e as ações dela decorrentes são importantes para fortalecer a sociedade civil à medida que ela supera o individualismo e possibilita a participação em ações coletivas.

Todavia, na maioria das vezes, o trabalho voluntário não tem por objetivo a superação das precárias condições socioeconômicas dos indivíduos, mas apenas a atenção a uma situação emergencial, não ocorrendo, por exemplo, o fomento à organização de atividades destas famílias ou dos indivíduos em cooperativas ou associações, possibilitando a qualificação mínima de homens, mulheres, adolescentes, ou a formação de grupos de debates para busca de soluções para a comunidade.

N ão obstante constatarmos nos discursos dos coordenadores das pastorais a preocupação em buscar soluções que vão além do paliativo, a mensagem da CN BB que afirma que as pastorais sociais expressa $(m)$ a compaixão de Jesus e o amor da mãe, traduzindo-os numa ação social de promoção humana junto aos setores mais pobres da sociedade (CNBB, 2001: 19), no dia-a-dia, os membros dessas pastorais defrontam-se com a miséria, com as limitações de um trabalho solidário voluntário, no qual não há muito a ser feito, seja porque as ações voluntárias são limitadas e instáveis por diversos fatores - disponibilidade do voluntário, poucos recursos, falta de capacitação técnica -, seja porque o trabalho a ser desenvolvido exige 0 envolvimento de técnicos qualificados de diferentes áreas, assistentes sociais, psicólogos, pedagogos, os quais, supomos, realizarão um trabalho contínuo e em rede.

Assim, uma outra conseqüência que constatamos dessas ações prolongadas é a dependência que se estabelece entre os atendidos e os mem- 
bros das pastorais, com reforço da situação em que vivem, não garantindo a inclusão social destes:

Porque já faz tempo que eu sou atendida pelos vicentinos, olha já bem uns dez anos. Vou fala pra você menina meu marido ficou doente e eu e ele já era aposentado, mas aposentando aquelestemposatrás era pouco... Ai me procuraram de mi dá a cesta básica, até hoje estão me dando. (Hilda)

Uns 3 anos...desde a época do padre Jair...ele é que falou, que vamos dar uma ajudinha para vocês...é que antes eu tive um problema na coluna e até o senhor Luís chegou a ver, e eu não podia nem andar...(Judite)

Por último, o fato de ser atendido por uma pastoral, isto é, por ser objeto de uma ação a princípio altruísta, revela que este tem que se submeter a determinadas normas e exigências feitas para receber a "ajuda", sob pena de se ver excluído do atendimento:

Não pedem nada pra receber ajuda, só pedem pra não faltar à missa, que é no quarto domingo, ir na reunião. Do início, eu não ia e eles falavam - mas você tem que vir, tem que vir...e então, eu comecei a participar. Eu tenho a maior alegria e o maior afeto por eles é o maior carinho que tenho por eles. (Ruth)

Eles querem que a gente trabalha, né. $A$ gente tem que se esforçar pra sair do buraco, ficar a vida inteira só pedindo e recebendo, não... A gente tem que trabalhar e seguir certinho: não arrumar mais marido, mais homem, não arrumar mais filho pra ficar sofrendo. Isso ai é o que eles falam pra gente. (Lia)

Por conseguinte, o merecimento por parte de quem deva ser objeto desta caridade acaba por estabelecer uma relação vertical e de favores, na 
qual os propósitos altruístas são suplantados pelos valores morais e éticos do voluntário, que tem por intenção enquadrar essa população em sua concepção de mundo. É importante destacarmos que esta tentativa de enquadramento não se dá de forma deliberada. Verificamos que ainda estes voluntários são de fato, movidos pela idéia do amor ao próximo, da solidariedade, apesar de esses sentimentos virem imersos nos ideais cristãos e da classe média, da qual a maioria deles provém.

Para criar uma relação horizontal, minimamente igualitária entre atendidos e voluntários, seria necessário que o discurso dos coordenadores dessas pastorais fosse colocado em prática, ou seja, a defesa dos direitos individuais e coletivos, o trabalho solidário. Entretanto tal fato exigiria 0 questionamento e a superação dos próprios valores morais e cristãos, já que haveria uma abertura e conseqüente compreensão da realidade social em que vivem, possibilitando elaborar novos valores morais e espirituais. $M$ as, seria interesse destes a própria mobilização e a superação de seu senso comum?

\section{Considerações finais}

Com a difusão da idéia cristã - ocidental de caridade, no Brasil, observamos que a assistência ao longo da história não apresentou um caráter sistemático e contínuo para melhoria das condições de vida daqueles que vivem na miséria, mas um caráter assistencialista, baseado em uma ajuda emergencial, fragmentada, autoritária e paternalista, exercida por voluntários, instituições religiosas e, em momentos de grave crise econômica ou institucional, pelo Estado, nas esferas federal, estadual e municipal, haja vista que caberia aos pobres aceitar a ajuda emergencial e procurar, por seus esforços, melhorar suas condições de vida.

A década de 90, porém, trouxe uma nova perspectiva para a assistência social, que passou a figurar como política pública, constituindo-se 0 
Estado como o grande responsável pelo enfrentamento à pobreza, e os usuários como cidadãos de direito, não sendo mais objeto da caridade de voluntários da sociedade civil.

Porém, se no âmbito legal e do discurso houve esta ruptura com o cotidiano das ações assistenciais, verificamos que, se a lei e seus artigos apresentam um caráter não religioso, mas secular, garantindo direitos aos usuários da assistência, os voluntários- aqui nos referimos aos católicosporque ainda são em maior número, continuam a atuar, mantendo uma certa hegemonia nas práticas e serviços nessa área, sob a perspectiva da caridade.

Com base nesta observação, consideramos que a consolidação de um novo modelo para a política de assistência social depende da superação de antigas práticas e concepções, depende de como os prestadores de serviços e seus usuários percebem a assistência: se na perspectiva do direito ou se ainda mesclam a antiga prática caritativa com o movimento da sociedade atual, isto é, a busca e garantia dos direitos individuais e coletivos.

Por este motivo, avaliamosque é importante e necessário desmistificar a idéia, largamente difundida em nossa sociedade, de que assistência à população carente de bens e serviços deve pautar-se na concepção de caridade, a qual, inadvertida ou deliberadamente, é utilizada por diferentes atores sociais, subordinados ou não a uma instituição religiosa.

\section{Referências}

BRASIL. Lei Orgânica da Assistência Social. Lei № 8.742 de 7 de dezembro de 1993.

CAMARGO, E.P.F. ; SO UZA, B.M. \& PIERU CCI, A. F.O . Comunidades eclesiais de base. São Paulo: 0 povo em movimento. 2aㅡ. ed. Petrópolis: Vozes, 1982. p. 59-81.

CNBB. 0 que é Pastoral Social? Cartilhas de pastoral social, №1. São Paulo: Ed. Loyola, 2001. 
GUSMÃO, R. A ideologia da solidariedade. Revista Serviço Social e Sociedade, no 62. São Paulo: Cortez, 2000. p. 93-112.

HOUTART, F. Mercado e religião. São Paulo: Cortez, 2003.

IVERN, F. \& BINGEMER, M.C. Doutrina social da igreja e teologia da libertação. São Paulo: Loyola, 1994.

LIBÂNIO, J.B. Pastoral numa sociedade de conflitos. Petrópolis: Vozes, 1982.

LÖWY, M. Ética católica e o espírito do capitalismo: o capítulo da sociologia da religião de Max Weber que não foi escrito. Cultura Vozes. Petrópolis: Vozes, v.92, n-01, p.86-100, 1998.

LÖWY, M. A guerra dos deuses: religião e política na América Latina. Petrópolis: Vozes, 2000.

NETTO, J.P. FHC e a política social: um desastre para as massas trabalhadoras. In: 0 desmonte da nação: balanço do governo FHC. Petrópolis: Vozes, 1999. p. $75-89$.

YAZBECK, M.C. A política social brasileira nos anos 90: refilantropização da questão social. Cadernos do CEAS, Salvador, no 164, p. 37-51, 1996. 


\section{Resumo}

Este artigo é resultado de uma pesquisa concluída em 2003, que teve por objetivo investigar como se expressa a concepção de direito nas ações das pastorais sociais da Igreja Católica de Londrina. Ao observarmos que a concepção de caridade e de direitos sociais caminha lado a lado no interior da Igreja Católica, uma indagação surgiu: como a concepção de direito social se expressa nas ações das pastorais sociais. A caridade é difundida como um dever cristão, uma ação que se expressa na experiência da solidariedade em relação ao outro que se encontra em situação que Ihe impossibilita garantir sua condição mínima de sobrevivência. Ao menos no discurso, as ações desenvolvidas não se limitam a fornecer cesta básica, roupas ou remédios. Constatamos que aqueles que atuam nas pastorais sociais movidos por valores como amor ao próximo e solidariedade, não perderam de vista, ao contrário, vêm reforçando a idéia de direito social.

Palavras-chave: igreja católica, pastorais sociais, caridade, direitos sociais, problemas sociais. 


\section{The Catholic Church, social assistance, and charity: approximations and disagreements}

\section{Claudia Neves da Silva}

This article is the result of a research study concluded in 2003, which aimed at investigating how the conception of Law is expressed in the actions of the socalled social pastoral commissions of the Catholic Church in Londrina, Brazil. By observing that the conception of charity and that of social rights walk side-bi-side within the Catholic Church, a question emerged: how is the conception of social right expressed in the actions of social pastoral commissions? Charity is preached 
as a Christian duty, as an action expressed in the experience of solidarity towards others who are in a situation that prevents them from having minimal living conditions. At least at discourse level, the actions developed are not limited to provide basic goods, clothes or medicine. We realized that those who act in social pastoral commissions, driven by values such as love to fellow human beings and solidarity, have not lost sight of the idea of social right - on the contrary, they have been reinforcing it.

Key words: Catholic Church, Social Pastoral Commissions; Charity; Social Rights; Social Problems 